\title{
TRANSFORMASI TEKNOLOGI ELEKTRONIK MELALUI APLIKASI SISTEM E-SYARIAH DAN I-SYARIAH DALAM SISTEM PENGURUSAN MAHKAMAH SYARIAH DI MALAYSIA
}

\section{(Transformation of Electronic Technology through the Application of e-Syariah and i-Syariah Systems in the Syariah Court Case Management System in Malaysia)}

\author{
Zulzaidi Mahmod \\ zulzaidi86@gmail.com
}

\section{Ahmad Hidayat Buang \\ ahidayat@um.edu.my}

Jabatan Syariah dan Undang-Undang,

Akademi Pengajian Islam, Universiti Malaya.

Pengarang koresponden (Corresponding author): *

Rujukan artikel ini (To cite this article): Zulzaidi Mahmod \& Ahmad Hidayat Buang. (2022). Transformasi teknologi elektronik melalui aplikasi sistem e-syariah dan i-syariah dalam Sistem Pengurusan Mahkamah Syariah Malaysia. Kanun: Jurnal Undang-undang Malaysia, 34(1), 45-74. http://doi.org. 10.37052/kanun.34(1)no3

\begin{tabular}{|llllll|}
\hline $\begin{array}{l}\text { Peroleh: } \\
\text { Received: 23/3/2021 }\end{array}$ & $\begin{array}{l}\text { Semakan: } \\
\text { Revised }\end{array} \quad$ 26/4/2021 & $\begin{array}{l}\text { Terima: } \\
\text { Accepted: 9/9/2021 }\end{array}$ & $\begin{array}{l}\text { Terbit dalam talian: } \\
\text { Published online }\end{array}$ & 2/1/2022 \\
\hline
\end{tabular}

\begin{abstract}
Abstrak
Implimentasi teknologi maklumat dalam institusi kehakiman syariah disambut baik oleh semua mahkamah syariah negeri di Malaysia melalui aplikasi sistem e-Syariah. Inovasi dan transformasi teknologi elektronik ini diteruskan oleh sebahagian mahkamah syariah termasuk mahkamah syariah di Sarawak yang membangunkan sistem baharu yang dinamakan i-Syariah, iaitu Sistem Pengurusan Pintar Syariah. Artikel ini bertujuan menganalisis pembangunan sistem Pengurusan Mahkamah Syariah melalui sistem e-Syariah pada peringkat Persekutuan dan i-Syariah yang diaplikasikan di Sarawak. Penelitian juga dilakukan terhadap modul yang dibangunkan dalam
\end{abstract}


sistem e-Syariah dan i-Syariah bagi dapatan maklumat penyelidikan yang menyeluruh. Metodologi penyelidikan dilakukan secara kualitatif terhadap perkembangan pembangunan sistem e-Syariah dan sistem i-Syariah serta melaksanakan metode komparatif dengan membandingkan sistem yang diguna pakai di mahkamah sivil dengan kandungan sistem yang diaplikasikan di institusi kehakiman syariah. Penyelidikan ini mendapati bahawa transformasi teknologi elektronik mahkamah syariah kurang menunjukkan perkembangan berbanding mahkamah sivil yang telah mengaplikasi e-Filing system (EFS), Case Management System (CMS), Queue Management System (QMS), Court Recording and Transcribing (CRT), Artificial Intelligence (AI) dan Community and Advocate Portal System (CAP). Walau bagaimanapun berdasarkan pelan pembangunan i-Syariah maka sistem-sistem yang diguna pakai pada peringkat mahkamah sivil ini akan diimplimentasikan di mahkamah syariah Sarawak untuk memastikan transformasi informasi teknologi maklumat seiring dengan perkembangan teknologi digital di Sarawak.

Kata kunci: e-Kerajaan, i-Syariah, e-Syariah, Sistem Pengurusan Kes Mahkamah Syariah, Jabatan Kehakiman Syariah Sarawak, intitusi kehakiman syariah

\begin{abstract}
The implementation of information technology in the Syariah Judiciary Institution has been well received by all Syariah Courts throughout Malaysia through the application of the e-Syariah system. The innovation and electronic technology transformation has been continued in several Syariah Courts, including the Syariah Court in Sarawak that developed a new system called the i-Syariah, or Syariah Intelligence Management System. This research paper is aimed at analysing the development of the Syariah Court Case Management System through the e-Syariah system at the federal level and the i-Syariah system that is applied in Sarawak. Analysis was also done on the modules developed in the e-Syariah and i-Syariah systems to acquire comprehensive research information. A qualitative research methodology was applied to the progress of e-Syariah and i-Syariah systems' development and a comparative methodology was applied to compare the systems applied in the Civil Court with the contents of systems applied in the Syariah Judiciary Institution. The research found that the electronic technology transformation in the Syariah Court has shown less development compared to that of the Civil Court, which applies e-Filing system (EFS), Case Management
\end{abstract}


System (CMS), Queue Management System (QMS), Court Recording and Transcribing (CRT), Artificial Intelligence (AI) and Community and Advocate Portal System (CAP). However, according to the $i$-Syariah development plan, various applications that are used in the Civil Court will be implemented in the Sarawak Syariah Court to ensure that the information and communication technology (ICT) transformation is in line with the digital technology development in Sarawak.

Keywords: e-Government, i-Syariah, e-Syariah, Syariah Court Case Management System, Sarawak Syariah Judiciary Department, Syariah judicial institution

\section{PENDAHULUAN}

Pemerkasaan institusi kehakiman syariah seiring dengan kepesatan pembangunan teknologi di Malaysia. Aplikasi sistem pengurusan kes di mahkamah syariah telah membuktikan dalam perkaitan perkara ini apabila sistem e-Syariah telah menjadi salah satu daripada projek rintis di awal pelaksanaane-Kerajaan diMalaysia. ${ }^{1}$ Terdapat tujuh programe-Kerajaanyang diperkenalkan oleh kerajaan Malaysia untuk menyokong peningkatan kualiti perkhidmatan kakitangan kerajaan, rakyat dan perniagaan. ${ }^{2}$ Perkembangan informasi komunikasi teknologi atau "information and communication technology"(ICT) sejak dua dekad terakhir ini menunjukkan bahawa kebanyakan kerajaan di seluruh dunia telah melihat fenomena ini sebagai peluang besar untuk meningkatkan kualiti penyampaian perkhidmatan awam. ${ }^{3}$ Kepesatan informasi komunikasi teknologi terhadap pembangunan negara dalam aspek pengurusan dan pentadbiran merupakan perkara yang diberikan penekanan oleh pihak kerajaan. Menyedari kepentingan teknologi

1 Rohana Husin, Rohaizah Saad \& Zakirah Othman. (2017). "E-Kerajaan: Tinjauan dan Perlaksanaannya di Malaysia”. Journal of Technology and Operations Management, 12(2) (December), 12.

2 Norshidah Mohamed, Husnayati Hussin and Ramlah Hussein. (2009). "Measuring Users' Satisfaction with Malaysia's Electronic Government Systems". Electronic Journal of e-Government, 7(3), 285.

3 Razlini Mohd Ramli. (2017). E-Government implementation challenges in Malaysia and South Korea: A comparative study. The Electronic Journal of Information Systems in Developing Countries, 80(7), 1-26. https://doi.org/10.1002/j.1681-4835.2017. tb00591.x 
maklumat dan komunikasi ini, maka kerajaan Malaysia telah melancarkan Multimedia Super Corridor (MSC) atau dikenali sebagai Koridor Raya Multimedia inisiatif untuk merangsang pertumbuhan teknologi maklumat dan komunikasi di Malaysia. ${ }^{4}$ MSC merupakan sebuah projek mega pada tahun 1996 yang merupakan strategi ke arah mencapai Wawasan 2020. ${ }^{5}$ Bagi memastikan transformasi perkhidmatan awam, maka pada 1997 pihak kerajaan telah melancarkan e-Kerajaaan ${ }^{6}$ yang mengaplikasikan teknologi maklumat (IT) kepada perkhidmatan kerajaan. ${ }^{7}$ Unit Pemodenan Tadbiran dan Perancangan Pengurusan Malaysia (MAMPU) telah diberikan kepercayaan untuk merancang, mengimplimentasi dan memantau inisiatif e-Kerajaan. ${ }^{8}$ MAMPU telah dipertanggungjawabkan terhadap projek ini ${ }^{9}$ termasuk dalam pembangunan aplikasi e-Syariah. Jabatan Kehakiman Syariah Malaysia (JKSM) telah dipertanggungjawabkan bagi memastikan keberkesanan aplikasi ini dalam usaha mempertingkatkan pengurusan dan pentadbiran kehakiman Syariah di negeri-negeri seluruh Malaysia melalui e-Syariah. Bagi merancakkan lagi perkembangan teknologi maklumat dalam institusi kehakiman syariah dalam perkhidmatan kerajaan, maka Jabatan Kehakiman Syariah Sarawak (JKSS) telah mengaplikasikan sistem i-Syariah (Syariah Intelligent Management System) versi 1 bermula 6 Julai 2020 yang dibangunkan oleh Sarawak Information Systems Sdn. Bhd. (SAINS) yang dikhususkan pemakaiannya di Sarawak bagi memastikan perkhidmatan kerajaan yang lebih efisien dan efektif. ${ }^{10}$ Kertas penyelidikan

$4 \quad$ Norshita Mat Nayan, Halimah Badioze Zaman \& Tengku Mohd Tengku Sembok. (2011). Measurement model to evaluate success of e-Government applications through visual relationship. Visual Informatics: Sustaining Research and Innovations, Second International Visual Informatics Conference, IVIC 2011, 295-304.

$5 \quad$ Rohana Husin et al. (2017). op.cit, h. 11.

6 Norazah Mohd Suki \& T. Ramayah. (2010). User acceptance of the e-Government services in Malaysia: Structural equation modelling approach. Interdisciplinary Journal of Information, Knowledge, and Management, 5, 395.

7 Fahmi Zaidi Bin Abdul Razak, Azlina Abu Bakar \& Wan Salihin Wong Abdullah. (2017). How perceived effort expectancy and social influence affects the continuance of intention to use e-Government: A study of a Malaysian Government Service”. Electronic Government, An International Journal, 13(1), 69.

$8 \quad$ M.N Norshita, B.Z Halimah, T.S Tengku Mohammad. (2010). "Public User Assessment of Malaysia's E-Government Applications". World Academy of Science, Engineering and Technology, No. 43, h. 813

9 Rohana Husin Rohaizah Saad \& Zakirah Othman. (2017). "E-Kerajaan: Tinjauan dan Perlaksanaanya di Malaysia". Journal of Technology and Operations Management, Jil. 12, No. 2 (December) 2017, h. 12. 
ini memfokuskan pengurusan kes di mahkamah syariah melalui pelaksanaan aplikasi e-Syariah dalam perkhidmatan awam kerajaan dan pemakaian sistem i-Syariah dalam sistem kehakiman syariah di Sarawak.

\section{SISTEM PENGURUSAN KES MAHKAMAH SYARIAH DI MALAYSIA}

Pengurusan dan pentadbiran institusi kehakiman syariah di Malaysia ditadbir pada peringkat negeri seperti yang diperuntukkan di bawah Jadual Kesembilan, Senarai 2, Senarai Negeri Perlembagaan Persekutuan. ${ }^{11}$ Jabatan Kehakiman Syariah Negeri (JKSN) dan juga Mahkamah Syariah Negeri (MSN) ialah agensi awam negeri yang bertindak mentadbir institusi kehakiman syariah pada peringkat negeri-negeri dari aspek pentadbiran dan pengurusan kes mahkamah syariah. Pihak JKSM pula ialah agensi pada peringkat kerajaan Persekutuan yang bertindak sebagai penyelaras dan koordinator bersama dengan JKSN dan MSN untuk menyeragamkan fungsi dan pelaksanaan gerak kerja institusi kehakiman syariah pada peringkat negeri. Perkara ini tidak terkecuali dari sudut pembangunan penyeragaman sistem pengurusan kes di mahkamah syariah melalui aplikasi e-Syariah yang dibangunkan khusus untuk mahkamah syariah di Malaysia.

\section{Sistem e-Syariah}

E-iaSyarh merupakan sebuah aplikasi "Government to Citizen" (G2C) yang bermaksud perkhidmatan kerajaan kepada masyarakat yang bertujuan untuk memperkasakan dan meningkatkan kecekapan pentadbiran mahkamah syariah di Malaysia. ${ }^{12}$ Projek e-Syariah merupakan antara tujuh inisiatif e-Kerajaan ${ }^{13}$ di bawah Koridor Raya Multimedia (MSC) pada tahun 1996. ${ }^{14}$ Kerajaan Malaysia telah memperuntukkan sebanyak RM39

10 Utusan Borneo Online. Pengenalan sistem i-Syariah mantapkan Jabatan Kehakiman Syariah Sarawak. Diakses pada 6 Julai 2020 daripada https://www.utusanborneo.com. my/2020/07/06/pengenalan-sistem-i-syariah-mantapkan-jabatan-kehakiman-syariahsarawak.

11 Perlembagaan Persekutuan Malaysia.

12 Norlida Ramly, Mohd, Fuaad Said, Choo Wei Chong, Suhaimi Ab. Rahman. (2015). Analyzing factors that affect e-syariah adoption by Shar'ie Lawyers". Jurnal Pengurusan, 43, 89-96.

13 Haniff Zainal Abidin. (2006). E-Government implementation in Malaysia: A comparison of Malaysia's and Korea's e-Government. (Unpublished Thesis Master in Public Policy at KDI School of Public Policy and Management, Cheongyang Seoul Korea. 
juta untuk reformasi pentadbiran syariah untuk mempertingkatkan kualiti perkhidmatan mahkamah syariah di Malaysia. ${ }^{15}$ E-Syariah merupakan satu rangkaian elektronik bagi sistem pengurusan kes yang menghubungkan mahkamah-mahkamah syariah negeri melalui JKSN dan MSN dengan pihak JKSM bagi tujuan penyelarasan dan juga perkongsian maklumat berkaitan dengan institusi kehakiman syariah di Malaysia.

Pemakaian Aplikasi e-Syariah di Malaysia sudah melebihi 18 tahun sejak pelancarannya. Cadangan bagi mewujudkan satu sistem pengurusan kes mahkamah syariah berdasarkan sistem elektronik berdasarkan hasil keputusan Mesyuarat Jemaah Menteri pada 13 Oktober 1999. Tujuan utama pembinaannya adalah untuk mewujudkan rangkaian e-Kerajaan pada peringkat Persekutuan di JKSM dengan mahkamah syariah negeri-negeri seluruh Malaysia dan agensi lain yang terlibat dengan operasi mahkamah syariah. ${ }^{16}$ Selain itu, implimentasi e-Syariah adalah untuk memperbaik kualiti perkhidmatan di mahkamah syariah. ${ }^{17}$ Selain itu, sistem ini juga diharapkan menjadi pemangkin koloborasi antara agensi Persekutuan dan agensi negeri untuk menyelaras proses kerja, borang, aturan kerja yang digunakan di mahkamah syariah. ${ }^{18}$ Usaha membangunkan sistem ini adalah untuk mempertingkatkan kecekapan pengurusan dan pentadbiran institusi kehakiman syariah seluruh Malaysia secara sistematik selaras dengan kehendak kerajaan Persekutuan bagi mewujudkan pengurusan dan pentadbiran secara e-Kerajaan. Pelaksanaan projek e-Syariah ini telah mula dilaksanakan pada Mac 2002 dan dilancarkan oleh Yang Amat Berhormat Perdana Menteri Malaysia pada ketika itu, Dato' Seri Dr. Mahathir Bin Mohamad pada 7 Februari 2003 di Hotel Marriot, Putrajaya. Pihak yang terlibat secara langsung terhadap projek pembangunan e-Syariah ialah MAMPU sebagai penyelaras, manakala JKSM sebagai pelaksana

14 Muhd Rosydi Muhammad. (2013). Managing the Implementation of E-Government in Malaysia: A Case of e-Syariah". Australian Journal of Basic and Applied Sciences, 7(8), 93.

15 Mornizan Yahya, Feridah Nadzar \& Baharom Abdul Rahman. (2012). Examining user acceptance of e-Syariah portal among syariah users in Malaysia. Journal Social and Behavioral Sciences, 67, 349-359. https://doi.org/10.1016/j.sbspro.2012.11.338.

16 Ramizah Wan Muhammad \& Khairunnasriah Abdul Salam. (2019). Kejayaan modal insan dan inovasi dalam pentadbiran mahkamah syariah: Membina model antarabangsa. Jurnal Syariah, 27(1), 36.

17 Mornizan Yahya et al. (2012). op.cit, 350.

18 Norlida Ramly et al. (2015). op.cit, 90. 
dan Sarawak Information System Sdn. Bhd. (SAINS) selaku pihak yang membangunkan sistem e-Syariah ini. ${ }^{19}$

\section{Aplikasi e-Syariah}

E-Syariah dibangunkan dengan beberapa aplikasi teras kepada pembangunan sistem ini. E-Syariah melibatkan 5 modul yang merangkumi, Sistem Pengurusan Kes Mahkamah Syariah (SPKMS), Sistem Pengurusan Peguam Syarie, Automasi Pejabat, Sistem Pengurusan Perpustakaan dan Portal e-Syariah. ${ }^{20}$ Selain itu Sistem jaringan juga dijadikan sebahagian modul pembangunan e-Syariah. ${ }^{21}$ Aplikasi yang melibatkan modul ini

\begin{tabular}{|c|c|c|c|c|}
\hline \multirow[t]{5}{*}{$\begin{array}{c}\text { Sistem jaringan } \\
\text { kepada } \\
\text { Pendaftaran } \\
\text { Negara }\end{array}$} & $\begin{array}{c}\text { Sistem } \\
\text { jaringan } \\
\text { kepada } \\
\text { Sistem } \\
\text { Kewangan }\end{array}$ & $\begin{array}{c}\text { Sistem jaringan } \\
\text { kepada Jabatan Agama }\end{array}$ & $\begin{array}{c}\text { Sistem } \\
\text { Perpusatkaan }\end{array}$ & $\begin{array}{c}\text { Portal } \\
\text { e-Syariah }\end{array}$ \\
\hline & $\begin{array}{c}\text { Carian dan } \\
\text { Pengambilan } \\
\text { Semula }\end{array}$ & Pengurusan Sumber & $\begin{array}{l}\text { Kalkulator } \\
\text { Pusaka }\end{array}$ & \\
\hline & $\begin{array}{l}\text { Pendaftaran } \\
\text { Peguam }\end{array}$ & $\begin{array}{c}\text { SISTEM } \\
\text { E-SYARIAH } \\
\end{array}$ & $\begin{array}{c}\text { Pendaftaran } \\
\text { Pelanggan }\end{array}$ & \\
\hline & $\begin{array}{c}\text { Pendaftaran } \\
\text { Kes }\end{array}$ & Peruntukan & Penjadualan & \\
\hline & $\begin{array}{c}\text { Sistem jaringan } \\
\text { kepada Peguam } \\
\text { Biro }\end{array}$ & $\begin{array}{l}\text { Sistem jaringan kepada } \\
\text { Jabatan Imigresen }\end{array}$ & $\begin{array}{l}\text { Sistem jaringan } \\
\text { kepada Polis }\end{array}$ & \\
\hline
\end{tabular}

Rajah 1 Pembangunan Sistem e-Syariah.

Sumber: Mohd Rosydi Muhammad ${ }^{22}$

19 Koleksi Ucapan Dato' Seri Dr. Mahathir Bin Mohamad, 7 Februari 2003, Hotel Marriot, Putrajaya "Majlis Pelancaran e-Syariah", diakses pada 1 Disember 2020 melalui laman web https://www.pmo.gov.my/ucapan/?m=p\&p=mahathir\&id=304.

20 Wan Satirah Wan Mohd Saman \& Abrar Haider. (2012). "Electronic Court Records Management: A Case Study". Journal of e-Government Studies and Best Practices, Vol. 2012, h. 6.; DOI: 10.5171/2012.925115.

$21 \quad$ Norlida Ramly et al. (2015). op.cit, h. 90.

22 Muhd Rosydi Muhammad. (2013). op.cit, h. 94. 
merupakan asas penting kepada pengurusan institusi kehakiman syariah yang lebih efektif dan menyeluruh. Aplikasi e-Syariah terus ditambah baik daripada e-Syariah versi 1 kepada e-Syariah versi $2^{23}$ yang lebih dinamik untuk kemudahan pengguna. Sistem e-Syariah yang dibangunkan merupakan sistem yang menyeluruh dengan mengambil kira aspek pengurusan kehakiman syariah di Malaysia. Secara keseluruhannya sistem e-Syariah dapat dilihat melalui ilustrasi pembangunan sistem ini seperti dalam Rajah 1.

Rajah 1 jelas menunjukkan bahawa pembangunan sistem e-Syariah mempunyai aspek yang lengkap dalam pengurusan mahkamah syariah. Selain itu, aplikasi yang telah diwujudkan dalam sistem ini termasuklah e-Bicara dan e-Nafkah. ${ }^{24}$ Modul e-Bicara merupakan sebahagian daripada aplikasi SPKMS e-Syariah yang dibangunkan untuk membantu Hakim Syarie merekodkan prosiding terus dalam sistem dengan lebih teratur. Hakim Syarie di Malaysia diberikan latihan khusus tentang pemakaian aplikasi e-Bicara untuk memudahkan urusan perbicaraan dari segi pengambilan nota keterangan kes sekali gus memudahkan Hakim Syarie untuk membuat alasan penghakiman. Sistem ini juga dapat membantu hakim dalam urusan prosiding kes dan penghakiman dijalankan dengan cepat dan teratur. ${ }^{25}$ Latihan e-Bicara ini adalah secara menyeluruh kepada semua Hakim Syarie termasuklah Hakim Syarie di Jabatan kehakiman Syariah Sarawak (JKSS). ${ }^{26}$ Bagi memastikan Hakim Syarie menggunakan e-Bicara secara optimum, maka pihak JKSM telah mengeluarkan satu arahan amalan khusus kepada e-Bicara di bawah Arahan Amalan No.

23 Wan Satirah Wan Mohd Saman \& Abrar Haider. (2012). op.cit, h. 6.

24 Ramizah Wan Muhammad \& Khairunnasriah Abdul Salam. (2019). op.cit, h. 36.

25 Portal Jabatan Kehakiman Syariah Malaysia, "E-Bicara", laman sesawang laman sesawang Jabatan Kehakiman Syariah Malaysia, dicapai 20 Februari 2019.; [http:// www.jksm.gov.my/index.php/awam/e-syariah/275-e-bicara].

26 Kursus Penggunaan Sistem e-Syariah (Modul e-Bicara) kepada Hakim Syarie JKSS dilaksanakan pada 5 Ogos 2015. Portal Rasmi Jabatan Kehakiman Syariah Sarawak, diakses pada 1 Disember 2020.[https://syariah.sarawak.gov.my/modules/ web/pages.php?lang=en\&mod=photo_gallery\&sub=photo_listing\&menu_id=\&sub_ $\mathrm{id}=\& \mathrm{alb}=27]$. 
6 Tahun $2013^{27}$ berkenaan dengan "Penggunaan Aplikasi e-Bicara oleh Hakim Syarie". Arahan Amalan tersebut telah mewajibkan Hakim Syarie menggunakan aplikasi e-Bicara bagi tujuan menyediakan nota perbicaraan dan alasan penghakiman mengikut tempoh masa yang telah ditetapkan. Perkara ini menunjukkan bahawa penggunaan aplikasi e-Bicara dalam kalangan Hakim Syarie di Malaysia terhadap informasi komunikasi teknologi adalah digalakkan oleh pihak JKSM, JKSN dan MSN.

Modul e-Nafkah merupakan submodul baharu bagi SPKMS yang dikhususkan penggunaannya kepada kakitangan Bahagian Sokongan Keluarga (BSK) JKSM yang di tempatkan di JKSN, MSN di seluruh Malaysia dan Jabatan Agama Islam Perak. BSK telah ditubuhkan oleh JKSM untuk mengatasi masalah kegagalan suami atau bapa terhadap pembayaran nafkah. ${ }^{28}$ BSK JKSM bertindak proaktif dengan mewujudkan sistem e-Nafkah yang bertindak sebagai fail maya dan berperanan secara dwifungsi dengan mempunyai bank data dan akan memuat naik segala perintah nafkah yang dikeluarkan oleh Mahkamah..$^{29} \mathrm{E}$-nafkah dibangunkan dengan mengambil kira peranan fungsi unit-unit yang telah diwujudkan. Unit tersebut termasuklah Unit Khidmat Nasihat Perundangan (UKNP), Unit Pengurusan Dana (UPD) dan Unit Penguatkuasaan dan Pelaksanaan Perintah (UPPP). ${ }^{30}$

27 Arahan Amalan No. 6 Tahun 2013 "Penggunaan Aplikasi E-Bicara oleh Hakim Syarie". Saya ingin menarik perhatian Y.A.A kepada keputusan Mesyuarat Arahan Amalan Mahkamah Syariah seluruh Malaysia tahun 2013 pada 27 hingga 29 Muharram 1435H bersamaan 1 hingga 3 Disember 2013 di Port Dickson, Negeri Sembilan telah bersetuju dan mengesahkan untuk menerima pakai Arahan Amalan mewajibkan para Hakim Syarie menggunakan aplikasi sistem e-Syariah bagi tujuan menyediakan nota perbicaraan dan alasan penghakiman mengikut tempoh masa yang telah ditetapkan. Arahan Amalan ini hendaklah dibaca bersama dengan Arahan Amalan No. 6 Tahun 2001 dan Arahan Amalan No.8 Tahun 2002.

Normi Abdul Malek. (2016). The family institution and its governing laws in Malaysia as a vanguard in protecting the society from social ailments: A shari'ah perspective. IIUM Law Journal, 24(2), 407. https://doi.org/10.31436/iiumlj.v24i2.235.

Khidmat Bantuan Bahagian Sokongan Keluarga. Portal MyGovernment, diakses pada 1 Disember 2020. [https://www.malaysia.gov.my/portal/content/28866?language $=\mathrm{my}$ ].

30 Roslina Che Soh@Yusoff, Nurhidayah Muhammad Hashim \& Mohd. Na'im Mokhtar. (2017). "Bahagian Sokongan Keluarga Membantu Anak Selepas Perceraian: Keberkesanan, Cabaran dan Perbandingan dengan Amalan Negara Maju". KANUN 29(2), 63 . 


\section{Portal e-Syariah}

Syariah Portal merupakan salah satu modul yang dibangunkan dalam sistem e-Syariah. Portal e-Syariah yang dibangunkan berfungsi sebagai pintu masuk (gateway) untuk orang ramai, agensi kerajaan dan mahkamah syariah untuk mengakses maklumat yang berkaitan dan menggunakan perkhidmatan e-Syariah di mana-mana dan pada bila-bila masa. ${ }^{31}$ Inovasi e-Kerajaan memberikan kesan besar kepada pengurusan dan pentadbiran, dan juga sebagai peranti untuk kemudahan dalam aspek kehidupan. Perkara ini ditunjukkan oleh portal e-Syariah yang telah menghubungkan semua mahkamah syariah di Malaysia dan bertindak sebagai kaunter sehenti untuk kebanyakan perkara yang berhubung dengan kehakiman Islam. ${ }^{32}$ E-Syariah berasaskan web portal membolehkan semua orang mengakses maklumat dan menggunakan sistem dengan mudah. ${ }^{33}$ Melalui Portal e-Syariah, orang ramai dapat memahami prosedur mahkamah, peraturan terkini, borangborang yang perlu diisi serta dapat mengemukakan pertanyaan tentang status kes. ${ }^{34}$ Perkhidmatan Portal e-Syariah adalah seperti Pendaftaran Kes atas Talian, Status Kes atas Talian, Pengiraan Faraid atas Talian, Direktori Mahkamah, Bahan rujukan. ${ }^{35}$ Selain itu, portal e-Syariah juga memberikan perkhidmatan berkenaan dengan profil JKSM, e-Borang, prosedur mahkamah, jadual kes mahkamah, arkib, maklumat Jurnal Hukum, undangundang syariah, nas al-Quran, fuqaha dan hadis, penerbitan maklumat (surat pekeliling, sulh, risalah JKSM), jenis kes, ulasan buku, maklumat Peguam dan perkhidmatan agensi kerajaan atas talian.

Portal e-Syariah telah memperbaik komunikasi dan mengurangkan jurang antara mahkamah syariah dan orang awam. ${ }^{36}$ Implimentasi e-Syariah boleh dikatakan sebagai kemajuan teknikal yang telah mendapat pengiktirafan di dalam negara seperti tempat pertama bagi ICT Quality

Mornizan Yahya et al. (2012). op.cit, 351.

Noore Alam Siddiquee. (2007). Public Service Innovations, Policy Transfer and Governance in The Asia-Pacific Region: The Malaysian Experience. JOAAG, 2(1), 86.

33 Muhd Rosydi Muhammad. (2009). Antecedents of IT alignment in public sector: Case of e-Syariah implementation in Malaysia". UK Academy for Information Systems Conference Proceedings 2009, 6; https:/aisel.aisnet.org/cgi/viewcontent.cgi?article= 1044\&context $=$ ukais2009.

34 Unit Teknologi Maklumat dan Komunikasi JAKESS. (2012). Pelan Strategik ICT Jabatan Kehakiman Syariah Negeri Selangor (JAKESS) 2011-2015. UTMK JAKESS, 11.

35 Mornizan Yahya et al. (2012). op.cit, h. 351.

36 Ibid. 
Award pada tahun 2007, ${ }^{37}$ Best EG Portal 2006 dan 4-star Government Portal. ${ }^{38}$ Portal e-Syariah secara dasarnya mempunyai maklumat yang menyeluruh bagi institusi kehakiman syariah di Malaysia. Walau bagaimanapun Portal e-Syariah ini tidak meletakkan pautan dan akses untuk alasan penghakiman yang dikeluarkan oleh mahkamah syariah seperti Portal Rasmi Pejabat Ketua Pendaftar Mahkamah Persekutuan Malaysia. Portal tersebut memaparkan alasan penghakiman terkini, alasan penghakiman mahkamah perusahaan dan akses kepada sistem e-Judgment khusus untuk Pegawai Kehakiman mahkamah sivil. ${ }^{39}$ Seharusnya portal e-Syariah perlu lebih menyeluruh termasuk memaparkan alasan penghakiman secara atas talian kerana pihak JKSM ada mengumpulkan alasan penghakiman daripada JKSN dan MSN untuk tujuan penerbitan dalam Jurnal Hukum seperti dalam Arahan Amalan No. 10 Tahun 2001.40 Oleh itu, wajar portal e-Syariah memaparkan alasan penghakiman mahkamah syariah bagi menambah baik mutu perkhidmatan institusi kehakiman termasuk keterbukaan penghakiman.

\section{Sistem Pengurusan Kes Mahkamah Syariah (SPKMS) e-Syariah}

Sistem Pengurusan Kes Mahkamah Syariah (SPKMS) merupakan salah satu modul dalam e-Syariah dan merupakan modul utama yang digunakan oleh mahkamah syariah di seluruh Malaysia. SPKMS merangkumi pendaftaran

\footnotetext{
37 Ramizah Wan Muhammad \& Khairunnasriah Abdul Salam. (2019). op.cit, h. 36.

38 Norlida Ramly et al. (2015). op.cit, h. 90.

39 Portal Rasmi Pejabat Ketua Pendaftar Mahkamah Persekutuan Malaysia. Alasan Penghakiman. Diakses pada 2 Disember 2020 daripada http://www.kehakiman.gov. my/ms/alasan-penghakiman.

40 Arahan Amalan JKSM No. 10 Tahun 2001, "Pengumpulan Kes-kes untuk Jurnal Hukum". Saya ingin menarik perhatian Y.A.A. kepada keputusan Mesyuarat Arahan Amalan Mahkamah Syariah seluruh Malaysia Bil.2/2000 pada 9-11 Oktober 2000 di Melaka dan keputusan Mesyuarat Ketua-Ketua Hakim Syarie kali ke 17 di Labuan 27 Oktober 2000 bersamaan dengan 26 Rejab 1421 telah bersetuju dan mengesahkan untuk menerima pakai arahan berhubung pengumpulan kes-kes untuk Jurnal Hukum. Ketua Pendaftar/ Pendaftar hendaklah membuat semakan dari masa ke semasa dan memilih kes-kes yang berkualiti dan mengemukakan sekurang-kurangnya 3 kes pada setiap bulan kepada Jabatan Kehakiman Syariah Malaysia dengan ditujukan kepada Pendaftar, kes-kes yang melibatkan Mahkamah Tinggi dan Mahkamah Rendah. Keutamaan juga diberikan kepada kes-kes Rayuan jika ada. Arahan ini juga berkaitan dengan Arahan Amalan No. 3 Tahun 2000. Arahan ini adalah berkuatkuasa serta merta.
} 
dalam talian, proses, bayaran, kes perceraian/tuntutan perkahwinan, jenayah, pusaka dan rayuan. ${ }^{41}$ SPKMS telah dilancarkan pelaksanaannya untuk mahkamah syariah di seluruh Malaysia secara berperingkat pada penghujung 2004. ${ }^{42}$ Sistem kerja melalui dalam talian (online) di mahkamah syariah seluruh Malaysia sentiasa dibuat penambahbaikan bagi mencanggihkan sistem ini agar menjadi lebih berfungsi dan memudahkan kerjasama dengan agensi-agensi yang terlibat dengan perkhidmatan institusi kehakiman di Malaysia. ${ }^{43}$ Kakitangan mahkamah syariah seluruh negara menggunakan sistem ini secara menyeluruh termasuk pengurusan kes Mal, Jenayah, Faraid, penjadualan kes serta statistik dan laporan.

Projek Sistem e-Syariah dapat membantu Pegawai Syariah melaksanakan tugas dengan lebih cekap dan berkesan. ${ }^{44}$ Sistem ini memudahkan pengurusan kes mahkamah secara lebih efisien, teratur dan sistematik. Walau bagaimanapun, perkembangan SPKMS melalui aplikasi ICT sehingga 2020 kurang menunjukkan perkembangan yang ketara seperti sistem yang diaplikasikan di mahkamah sivil. Tranformasi kehakiman mahkamah sivil di Malaysia di antara tahun 2009-2012 telah memberikan penekanan terhadap pengurusan kes daripada sebelumnya.$^{45}$ Mahkamah sivil Malaysia antara negara yang mempraktiskan mahkamah tanpa kertas (paperless court) dan sistem tersebut dikenali sebagai "e-courts". ${ }^{46}$ Projek e-Courts dilaksanakan bertujuan (1) membenarkan pemfailan kes dalam talian bagi mencapai tujuan pejabat tanpa kertas (paperless office), (2) menjimatkan ruang simpanan dan sumber manusia, (3) membenarkan

$41 \quad$ Norlida Ramly et al. (2015). op.cit, 90.

42 Jabatan Kehakiman Syariah Malaysia. (2005). Pekeliling Ketua Pengarah/ Ketua Hakim Syarie Jabatan Kehakiman Syariah Malaysia Bilangan 2 Tahun 2005, "Garis Panduan Bagi Penggunaan Modul dan Kemudahan Peguam dalam Sistem Pengurusan Kes Mahkamah Syariah (SPKMS) e-Syariah” berkuatkuasa pada 19 Oktober 2005.

43 Ibid.

44 Unit Teknologi Maklumat dan Komunikasi JAKESS. (2012). Pelan Strategik ICT Jabatan Kehakiman Syariah Negeri Selangor (JAKESS) 2011-2015. UTMK JAKESS 11.

45 Norman Zakiyy \& Kamal Halili Hassan. (2015). "Prospects of Using Early Neutral Evaluation in Case Management of Complex Civil Cases in Malaysia". European Journal of Economics and Business Studies, v. 1 no. 3, h. 10.

46 Nurul Aiqa Mohamad Zain et. al. (2018). "Developing Legal Framework for E-Court in Judicial Delivery". International Journal of Engineering \& Technology, 7(3.7), 204. DOI: 10.14419/ijet.v7i3.7.16351. 
akses segera kepada dokumen semasa perbicaraan dan (4) mengelakkan dokumen palsu. ${ }^{47}$

Sistem mahkamah sivil telah mengambil inisiatif dengan mengaplikasikan Electronic Courts Systems yang terdiri daripada Sistem e-Filing (EFS), Case Management System (CMS), Queue Management System (QMS) dan Court Recording and Transcribing (CRT). ${ }^{48}$ Selain itu, aplikasi terkini pada tahun 2020 yang yang dibangunkan di mahkamah sivil menggunakan sistem kecerdasan buatan (artificial intelligence) atau AI yang dilaksanakan di Sabah dan Sarawak. Sistem ini dibangunkan oleh Sarawak Information Systems Sdn. Bhd. (SAINS) yang merupakan syarikat di bawah kerajaan negeri Sarawak ${ }^{49}$ AI boleh dijelaskan sebagai "allowing a machine to behave in such a way that it would be called intelligent if a human being behaved in such a way". ${ }^{50} \mathrm{AI}$ bagi penggunaan Mahkamah di Sabah dan Sarawak digunakan untuk membantu dalam urusan penjatuhan hukuman terhadap kes dadah dan rogol. ${ }^{51}$

Kedua-dua perbicaraan tersebut melibatkan peruntukan bagi kesalahan pemilikan dadah di bawah Seksyen 12(2) Akta Dadah Berbahaya dan kesalahan rogol di bawah seksyen 376(1) Kanun Keseksaan. ${ }^{52}$ Sistem AI ini akan menganalisis pangkalan data kes antara tahun 2014 hingga 2019 di Sabah dan Sarawak sebelum membuat cadangan kepada mahkamah. ${ }^{53}$ Transformasi sistem elektronik di mahkamah sivil dilihat lebih berkembang berbanding mahkamah syariah dari segi pengurusan kes. Sistem SPKMS e-Syariah yang dibangunkan memerlukan transformasi agar seiring dengan kepesatan penggunaan sistem elektronik di mahkamah.

47 Wan Satirah Wan Mohd Saman \& Abrar Haider. (2012). op.cit, h. 5.

$48 \quad$ Ibid.

49 Claire Lim \& Rachel Gong. (2020). Artificial intelligence in the courts:AI sentencing in Sabah and Sarawak. Khazanah Research Institute (KRI), 3.

50 Reiling, A.D. (Dory). (2020). Courts and artificial intelligence. International Journal for Court Administration, 11(2), 2. DOI: http://doi.org/10.36745/ijca.343.

51 The Star Online. Digital justice: Liew says AI to aid in sentencing for drug, rape trials in Sabah from Feb 17'. Diakses pada 2 Disember 2020 daripada https://www.thestar. com.my/news/nation/2020/01/30/digital-justice-liew-says-ai-to-mete-out-sentencesfor-drug-rape-trials-in-sabah-from-feb-17.

$52 \quad$ Claire Lim \& Rachel Gong. (2020). op.cit, h. 3.

53 New Straits Times. "Malaysian judiciary makes history, uses AI in sentencing". 19 Februari 2020. Diakses pada 2 Disember 2020 daripada https://www.nst.com.my/ news/nation/2020/02/567024/malaysian-judiciary-makes-history-uses-ai-sentencing. 


\section{PEMBANGUNAN SISTEM BAHARU BAGI PENGURUSAN KES MELALUI IMPLEMENTASI SISTEM I-SYARIAH DI JABATAN KEHAKIMAN SYARIAH SARAWAK}

Syariah Intelligent Management System yang dikenali sebagai i-Syariah merupakan sistem pengurusan mahkamah yang diaplikasikan oleh Jabatan Kehakiman Syariah Sarawak (JKSS). i-Syariah merupakan sebuah aplikasi yang menyeluruh bagi mempertingkatkan keberkesanan penyampaian perkhidmatan kehakiman syariah kepada Peguam Syarie, agensi kerajaan, agensi swasta dan seluruh masyarakat di Sarawak berdasarkan teknologi digital. Pembangunan transformasi digital ini selaras dengan kehendak YAB Datuk Patinggi (Dr) Abang Haji Abdul Rahman Zohari bin Tun Datuk Abang Haji Openg (Ketua Menteri Sarawak), iaitu bagi mendorong pertumbuhan ekonomi Sarawak maka inisiatif pemangkin yang digarapkan termasuklah kerajaan Digital menggunakan teknologi. ${ }^{54}$ Melalui teknologi maklumat dan komunikasi (ICT), pelbagai aktiviti ekonomi, interaksi profesional dan transaksi komersial berlaku, sehingga menjana ekonomi digital. ${ }^{55}$ Sistem i-Syariah ini dibangunkan oleh Sarawak Information Systems Sdn. Bhd. (SAINS). SAINS merupakan cabang ICT kerajaan negeri yang melaksanakan operasi ICT di Sarawak. ${ }^{56}$ SAINS juga mempunyai pengalaman yang luas terhadap pembangunan sistem teknologi di Sarawak dan sistem pengurusan mahkamah seperti Laman Web Mahkamah Tinggi Sabah dan Sarawak, ${ }^{57}$ artificial intelligence (AI) di mahkamah sivil Sabah dan Sarawak ${ }^{58}$ dan e-Syariah Negara Brunei. Sistem e-Syariah versi 1 yang

54 Opening Address and Official Launching of IDECS 2020, "Data and Innovation in Accelerating Social and Economic Prosperity”, By YAB Datuk Patinggi (Dr) Abang Haji Abdul Rahman Zohari bin Tun Datuk Abang Haji Openg (Chief Minister of Sarawak) 7 October 2020 at Borneo Convention Centre Kuching (BCCK).; official website office of the chief minister of Sarawak, https://cm.sarawak.gov.my/modules/ web/pages.php?mod $=$ speeches\&sub $=$ speeches_view\&menu_id $=\&$ sub_id $=\&$ nid $=79$.

55 Claudius Mitchell Hamarah and Fitri Suraya Mohamad. (2020). "Mathematical Cognition and Big Data Analytics: Are Sarawak Teachers Ready?" Journal of Cognitive Sciences and Human Development. 6(1), March, 1-8. https://doi.org/10.33736/ jcshd.1591.2020.

56 Syahrul Nizam Junaini \& Nadianatra Musa. (2007). Success of e-Government Initiative in Sarawak. Public Sector Ict Management Review, January, 47.

57 Portal The High Court Of Sabah And Sarawak, "Launching Of The High Court Of Sabah And Sarawak Website In Kuching, Sarawak". Diakses pada 2 Disember 2020.; [https://judiciary.kehakiman.gov.my/portals/web/home/article_view/0/460//1].

58 Claire Lim \& Rachel Gong. (2020). op.cit, h. 3. 
digunakan oleh mahkamah syariah seluruh Malaysia juga merupakan sistem yang telah dibangunkan oleh pihak SAINS. ${ }^{59}$ Pemilihan pihak SAINS sebagai pemaju bagi sistem ini adalah untuk memastikan pembangunan sistem berjalan dengan lancar dan teratur berdasarkan pengalaman SAINS terhadap pembangunan sistem pengurusan kehakiman.

\section{Tujuan Pembangunan i-Syariah}

Sistem i-Syariah yang dibangunkan khusus di Sarawak bertujuan untuk mentransformasikan sistem pengurusan mahkamah syariah baharu yang lebih komprehensif, menyeluruh, efektif dan terkini berdasarkan perkembangan teknologi digital di Sarawak. Kematangan terhadap keperluan teknologi digital melalui i-Syariah dapat meningkatkan kualiti penyampaian perkhidmatan kehakiman syariah dan dapat menghubungkan semua mahkamah syariah di seluruh Sarawak secara teknologi elektronik untuk mengurus dan menyelaraskan maklumat. ${ }^{60}$ Terdapat tiga justifikasi asas pembangunan sistem i-Syariah, iaitu (1) sistem ini memudahkan perkhidmatan JKSS di seluruh Sarawak serta dapat mengintegrasikan sistem dengan agensi lain, (2) penyediaan data statistik yang komprehensif kepada kerajaan negeri Sarawak dan memacu prestasi dan imej JKSS yang baik secara umum dan (3) aplikasi sistem yang dapat merealisasikan fungsi JKSS terhadap Pelan Transformasi JKSS 2020-2030, inisiatif Balanced Scorecard (BSC) JKSS serta pematuhan terhadap pensijilan MS ISO 9001: 2015 dan MS 1900: 2015. ${ }^{61}$ Pemakaian aplikasi sistem i-Syariah sebagai sistem pengurusan mahkamah syariah adalah untuk memperbaik proses kerja yang terkini dan bersifat teknikal serta menggantikan sistem mahkamah yang sedia ada. Sebelum ini segala pengurusan kes di Sarawak dibuat berdasarkan SPKMS e-Syariah secara keseluruhannya. Walau bagaimanapun bermula pada 6 Julai 2020 Pihak JKSS telah mengguna pakai sistem i-Syariah bagi pengurusan kes di mahkamah syariah. Walau

59 Koleksi Ucapan Dato' Seri Dr. Mahathir Bin Mohamad, 7 Februari 2003, Hotel Marriot, Putrajaya "Majlis Pelancaran e-Syariah"; https://www.pmo.gov.my/ ucapan $/ \mathrm{m}=\mathrm{p} \& \mathrm{p}=$ mahathir\&id $=304$.

60 Jabatan Kehakiman Syariah Sarawak. (2019). "DGC Paper No. 2018/02/02" dibentangkan di Wisma Bapa di hadapan Setiausaha Kerajaan negeri Sarawak pada 14 Mac 2019.

61 Ibid. 
bagaimanapun aplikasi sistem e-Syariah masih lagi digunakan oleh pihak JKSS bagi menyemak kes yang terdahulu yang didaftarkan melalui sistem ini. Melalui pembangunan i-Syariah yang diaplikasikan di Sarawak akan mengintegrasikan dengan sistem e-Syariah yang sedia ada dari aspek tertentu untuk melancarkan pengurusan mahkamah syariah melalui teknologi elektronik.

\section{Sejarah Pembangunan i-Syariah}

Kewujudan i-Syariah boleh dikatakan berkesinambungan daripada pelaksanaan aplikasi sistem e-Syariah yang dilaksanakan oleh JKSM. Cadangan mewujudkan sebuah sistem baharu bagi mengikut arus transformasi digital Sarawak dibangkitkan dalam Retreat Batang Ai Sri Aman Sarawak oleh Pihak Pengurusan Jabatan Kehakiman Syariah Sarawak pada Mac 2018. Rentetan daripada itu perbincangan diteruskan pada Disember 2018 dalam Bengkel Pemurnian Dokumen Pelan Transformasi JKSS di Imperial Hotel Kuching Sarawak. Perbincangan dilakukan secara dasar untuk menilai kewujudan sistem pengurusan mahkamah yang baharu memandangkan aplikasi sistem e-Syariah tidak memenuhi kriteria pengurusan kes di Sarawak. Perkara yang menjadi asas kepada pewujudan sistem baharu adalah berkenaan dengan bidang kuasa kes di Sarawak dari sudut pengurusan harta termasuk Pengurusan Pusaka. Berdasarkan Perlembagaan Persekutuan di bawah Jadual Kesembilan, Senarai 2, Senarai Negeri meletakkan berkenaan negeri berbidang kuasa terhadap pewarisan. ${ }^{62}$ Namun begitu, hal ini terhad pada perakuan tentang ahli-ahli waris yang berhak dan kadar bahagian mereka mengikut faraid sahaja. ${ }^{63}$ Oleh itu, mahkamah syariah tidak mempunyai kuasa untuk memerintahkan pengagihan terhadap harta pusaka ${ }^{64}$ tetapi hanya mengeluarkan perintah

\footnotetext{
62 Perlembagaan Persekutuan Malaysia.

63 Pekeliling Ketua Pengarah Tanah Dan Galian Persekutuan Bilangan 7/2017 "Peritah, Sijil Atau Perakuan Faraid Tidak Boleh Digunakan Bagi Tujuan Pendaftaran Turun Milik Harta Pusaka Si Mati”, h. 1.; Official Portal Department of Director General of Lands \& Mines, Ministry of Energy and Natural Resources, https://www.jkptg. gov.my/en/panduan/senarai-pekeliling/pekeliling-terbuka/item/pekeliling-ketuapengarah-tanah-dan-galian-persekutuan-bilangan-7-2017

64 Noraini Noordina, Adibah Shuib, Mohammad Said Zainol, Mohamed Azam Mohamed Adil. (2012). Review on issues and challenges in Islamic inheritance distribution in Malaysia”. International Journal of Sustainable Development, 03(12), 30.
} 
perakuan sahaja. Walau bagaimanapun, situasi ini berbeza dengan keadaan di Sarawak yang mempunyai bidang kuasa yang lebih luas. Perintah yang dikeluarkan oleh mahkamah syariah di Sarawak boleh digunakan bagi tujuan turun hak milik pusaka si mati. ${ }^{65}$ Permintaan JKSS bagi meluaskan penggunaan sistem faraid yang lebih meluas tidak dapat dipenuhi oleh sistem e-Syariah yang menyebabkan cadangan pewujudan sistem baharu ini selain daripada faktor perkembangan teknologi digital dalam pengurusan institusi kehakiman seperti di institusi kehakiman sivil. Satu pembentangan pewujudan sistem baharu ini telah dibentangkan di hadapan Setiausaha Kerajaan Negeri Sarawak pada 29 April 2019 dan proses pembangunan diteruskan secara berjadual.

Pada 23 Ogos 2019 "kick off" sistem i-Syariah telah dilancarkan di Ibu Pejabat JKSS oleh Ketua Hakim Syarie JKSS YAA Datu Haji Awang Suhaili bin Ledi. Satu Majlis Pra-Pelancaran Sistem i-Syariah telah dilancarkan oleh Menteri Muda Hal Ehwal Islam dan Dewan Bandaraya Kuching Utara (DBKU) Datuk Dr. Abdul Rahman Junaidi pada 6 Julai $2020 .{ }^{66}$ Tarikh tersebut juga merupakan tarikh pertama penggunaan sistem

Jadual 1 Sejarah Sistem Pengurusan Mahkamah Syariah di Sarawak.

\begin{tabular}{|l|l|}
\hline 1991 & Mahkamah Syariah Information System \\
\hline 1995 & $\begin{array}{l}\text { Court Case Information System (COCIS)-kemudian } \\
\text { dinamakan SEMAK }\end{array}$ \\
\hline 1998 & $\begin{array}{l}\text { SEMAK diperkenalkan ke Mahkamah Syariah } \\
\text { Persekutuan Kuala Lumpur }\end{array}$ \\
\hline 2002 & $\begin{array}{l}\text { SAINS membangunkan e-Syariah untuk kegunaan } \\
\text { seluruh Malaysia termasuk Sarawak }\end{array}$ \\
\hline 2019 & i-Syariah diluluskan \\
\hline 2020 & i-syariah digunakan bagi fasa 1 \\
\hline
\end{tabular}

Sumber: Jabatan Kehakiman Syariah Sarawak.

65 Najaruddin Nedri, Pengurus Projek I-Syariah JKSS. Temu bual pada 1 Disember 2020.

66 New Sarawak Tribune. "State Syariah Dept first to adopt i-Syariah" 6 Julai 2020. Diakses pada 2 Disember 2020; https://www.newsarawaktribune.com.my/statesyariah-dept-first-to-adopt-i-syariah/ 
i-Syariah fasa pertama terhadap pengurusan mahkamah syariah di Sarawak. Pembentukan sistem i-Syariah bukanlah sistem baharu dalam pengurusan mahkamah syariah di Sarawak, tetapi suatu transformasi teknologi secara berperingkat bagi memastikan penyampaian perkhidmatan yang lebih efektif. Perkara ini dapat dilihat melalui Jadual 1.

\section{Aplikasi Sistem i-Syariah dalam Pengurusan Mahkamah Syariah}

Sistem i-Syariah yang dibangunkan mempunyai dua fasa yang melibatkan lebih 28 modul dan tujuh subsistem utama kepada pemakaian sistem ini. ${ }^{67}$ Cadangan pembangunan sistem ini berdasarkan konsep transformasi teknologi kepada institusi kehakiman agar selari dengan gerak kerja semasa dan perkembangan pemakaian teknologi yang terkini. Tujuh subsistem utama Sistem Pengurusan Kes Mahkamah Syariah (SPKMS) adalah seperti Rajah 2.

Subsistem yang dibangunkan ini sentiasa dikemas kini dari semasa ke semasa untuk memastikan sistem yang dibuat mesra pengguna dan komprehensif tanpa gangguan. ${ }^{68}$ Aplikasi sistem yang dibangunkan ini dilakukan secara berfasa untuk memastikan gerak kerja pembangunan lebih tersusun dan teratur berdasarkan keutamaan fungsi mahkamah syariah di Sarawak. Modul yang dibangunkan dalam sistem i-Syariah ialah aplikasi modul digunakan bagi pengurusan mahkamah syariah yang berkaitan dengan subsistem yang dinyatakan di atas. SPKMS fasa pertama membangunkan modul antaranya termasuklah Modul Pendaftaran Kes, Modul Pengurusan Pihak-Pihak, Modul Pengurusan Resit, Modul Pengurusan Templat Borang, Modul Pengurusan Dokumen, Modul Sulh, Modul Pengurusan Jadual, Modul Pengurusan Perancangan, Modul Pengurusan Kalender Hijri, Modul Penghakiman, Modul Pengurusan Kes Rayuan, Modul Pengurusan Kes Semakan, Modul Statistik dan Laporan, Modul Carian Kes, Modul Pemantauan Kes. ${ }^{69}$

\footnotetext{
67 Jabatan Kehakiman Syariah Sarawak "Pembentangan Modules Breakdown for RMK11 (2019-2020)" pada 29 April 2020 di Wisma Bapa Malaysia Sarawak.

68 Najaruddin Nedri, Pengurus Projek I-Syariah JKSS. Temubual pada 1 Disember 2020.

69 Ibid.
} 
Aplikasi modul ini dalam sistem i-Syariah dibuat secara terancang untuk memastikan pengguna sistem terutamanya Hakim Syarie memahami pemerkasaan transformasi teknologi dalam kehakiman syariah. Bagi subsistem i-Syariah yang lain juga mempunyai modul khusus secara menyeluruh yang dibangunkan pada fasa kedua. Modul tersebut termasuklah Modul Tandatangan Digital, Modul Bahagian Sokongan Keluarga (BSK), Modul Pengurusan Menunggu, Sistem Kaunter, Modul Rujukan Undang-Undang, Bayaran Atas Talian, Modul Fungsi "offline", Sistem Pendawa Syarie, Sistem Pengurusan Keselamatan, Integrasi dengan Agensi Berkaitan $^{70}$ dan lain-lain lagi. Secara keseluruhan aplikasi sistem

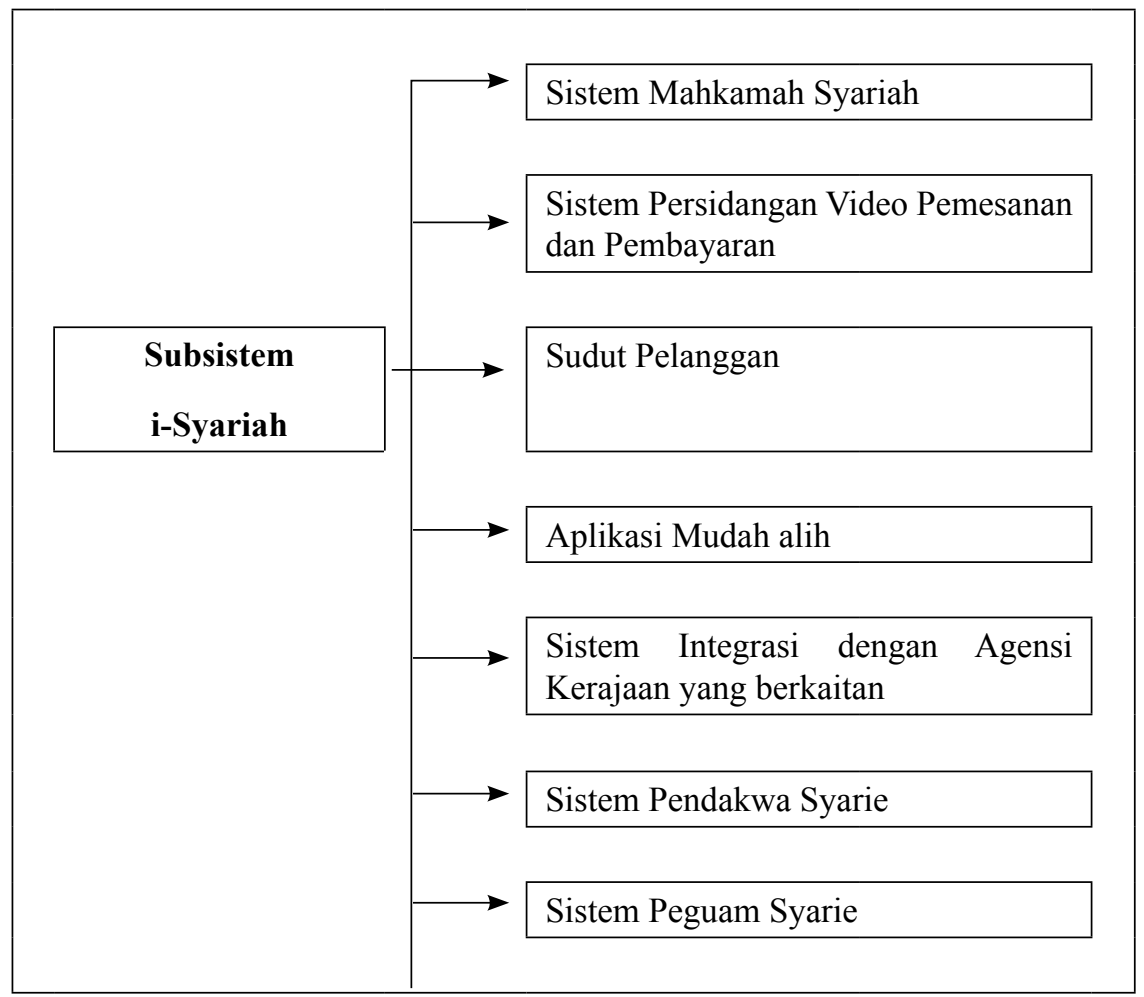

Rajah 2 Sistem i-Syariah yang dilaksanakan oleh JKSS.

70 Jabatan Kehakiman Syariah Sarawak "Pembentangan Modules Breakdown for RMK-12" pada 25-27 November 2020 di Sibu Sarawak. Ilustrasi telah dialih bahasa daripada Bahasa Inggeris kepada Bahasa Malaysia. 


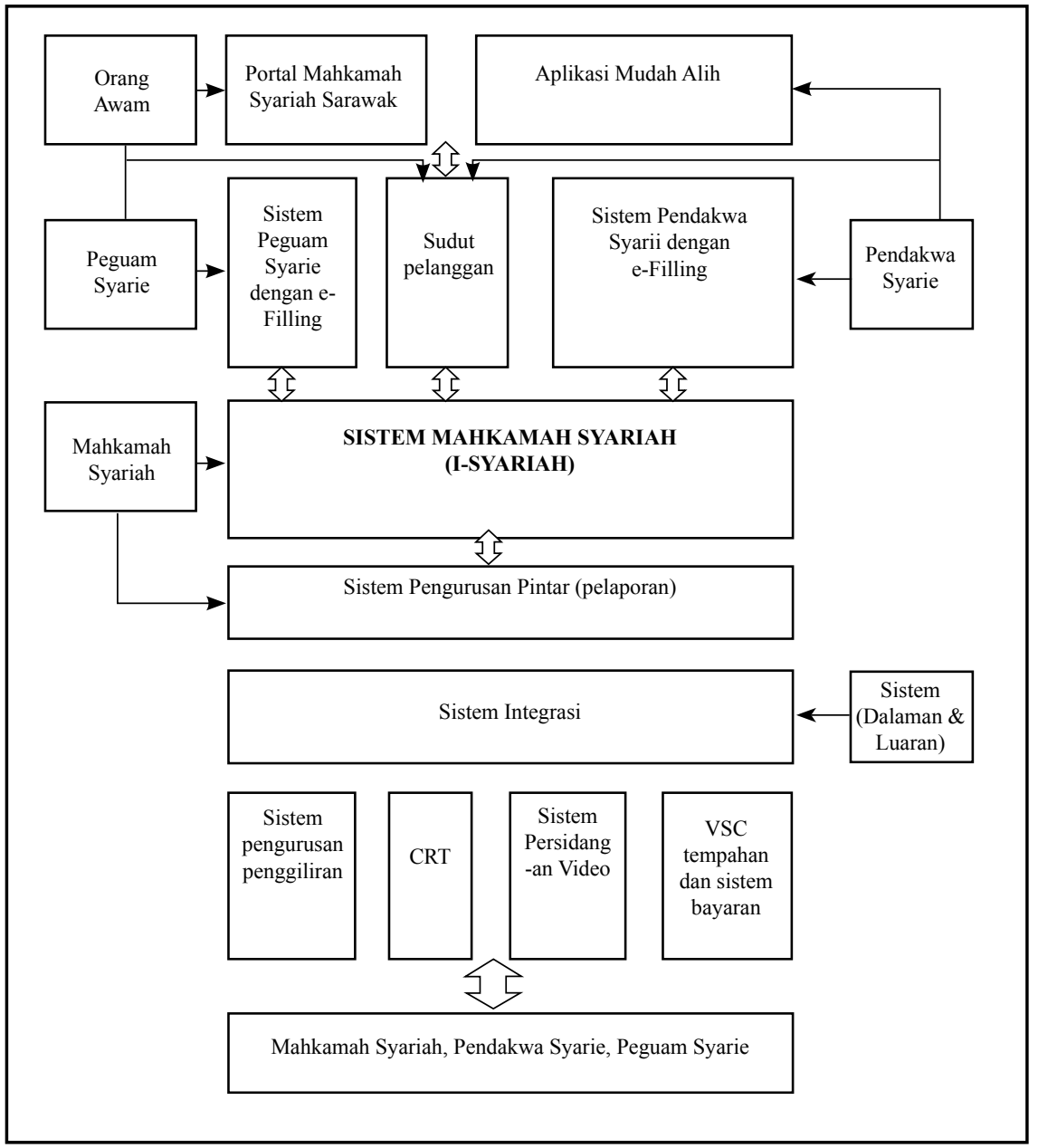

Rajah 3 Pembangunan Sistem i-Syariah. ${ }^{71}$

Sumber: Jabatan Kehakiman Syariah Sarawak

i-Syariah yang melibatkan pengurusan mahkamah syariah dan institusi kehakiman syariah di Sarawak boleh dilihat melalui Rajah 3.

Rajah 3 menunjukkan bahawa pembangunan i-Syariah mengambil kira aspek yang berkaitan mahkamah syariah seperti Peguam Syarie,

71 Kamal Halili Hassan \& Maizatul Farisah Mokhtar. (2011). The e-Court system in Malaysia. International Conference on Education and Management Technology, 242. 
Pendakwa Syarie dan orang awam. Pembangunan i-Syariah ini juga melihat kehendak semasa yang amat diperlukan oleh institusi kehakiman syariah seperti sistem yang telah diaplikasikan di mahkamah sivil. Aplikasi yang diimplementasikan terhadap mahkamah sivil oleh i-Syariah antaranya termasuklah Que Management System (QMS), Court Recording and Transcription (CRT) System, dan E-Filling. Sistem e-Filling merupakan sistem elektronik bagi tujuan pemfailan kes secara dalam talian. ${ }^{72}$ Firma guaman tidak perlu mengemukakan fizikal dokumen secara manual kepada mahkamah. Sistem ini juga membolehkan peguam yang berada di manamana tempat menghantar dokumen atau saman secara dalam talian. ${ }^{73}$ Video Conferencing System (VCS) juga dimasukkan dalam pelan sistem i-Syariah berdasarkan faktor geografi Sarawak dan untuk memudahkan urusan mahkamah dengan masyarakat awam. ${ }^{74}$ Sarawak merupakan negeri yang terbesar di Malaysia dengan keluasan $124,450 \mathrm{~km}^{2}$ dan populasi sebanyak 2.5 juta. $^{75}$ Maka teknologi amat diperlukan masa kini untuk memastikan perkhidmatan kepada masyarakat dapat disampaikan dengan baik. Salah satu modul yang dibangunkan dalam sistem i-Syariah ini ialah sistem integrasi dengan agensi-agensi yang berkaitan bagi memudahkan urusan mahkamah. Cadangan agensi dan sistem yang berkaitan bagi tujuan integrasi termasuklah integrasi dengan e-Kiswa, e-Dakwa and e-Munakahat, integrasi dengan Pustaka, integrasi dengan sistem SIFBAS, integrasi dengan SarawakID, integrasi dengan sistem JKSM e-Syariah ${ }^{76}$ dan lain-lain lagi. Tujuan integrasi sistem bukan sekadar satu sistem jaringan tetapi juga untuk memudahkan perkhidmatan mahkamah syariah dengan agensi lain dalam masa yang sama memudahkan urusan pelanggan bagi tujuan pendaftaran kes dan pembayaran. Berdasarkan pembangunan

72 Jabatan Kehakiman Syariah Sarawak "Pembentangan Modules Breakdown for RMK11 (2019-2020)" pada 29 April 2020 di Wisma Bapa Malaysia Sarawak.

73 Gan Chee Keong. (2017). Judicial Reforms through the Use of Technology in Malaysia. European Academic Research, V(1), April, 401.

74 Najaruddin Nedri, Pengurus Projek I-Syariah JKSS. Tembual pada 1 Disember 2020.

75 Prashobh Karunakaran. (2014). Electric power grid optimization for the state of Sarawak as an example fordeveloping countries. International Journal of Electrical and Electronic Engineering \& Telecomunication, 3(2), April, 98.

76 Jabatan Kehakiman Syariah Sarawak "Pembentangan Modules Breakdown for RMK11 (2019-2020)" pada 29 April 2020 di Wisma Bapa Malaysia Sarawak. 
sistem i-Syariah ini menunjukkan institusi kehakiman syariah di Sarawak sudah maju setapak untuk setanding dengan mahkamah sivil dari segi teknologi digital. Rangsangan pembangunan ini juga menunjukkan bahawa Kerajaan Sarawak berdedikasi menggunakan ICT dan internet untuk memajukan prosesnya dan menyampaikan perkhidmatan berkualiti. ${ }^{77}$ Pembangunan sistem i-Syariah masih dibangunkan oleh pihak SAINS sewaktu penyelidikan ini dilakukan pada akhir tahun 2020.

\section{DAPATAN DAN PERBINCANGAN}

Penggunaan teknologi elektronik dalam sistem kehakiman syariah di Malaysia telah diaplikasikan melalui sistem e-Syariah. Perbincangan berkenaan dengan aplikasi sistem e-Syariah telah dijelaskan seperti di atas yang menerangkan bahawa sistem ini digunakan di seluruh mahkamah syariah di Malaysia. Secara dasarnya sistem ini merupakan satu sistem yang menyeluruh yang mengambil kira peranan pihak mahkamah, Peguam Syarie, masyarakat dan agensi yang berkaitan. Sistem e-Syariah yang dibangunkan sudah menggunakan versi-2 dan penggunaan e-Syariah keseluruhannya telah menghampiri dua dekad. Selain sistem e-Syariah terdapat juga beberapa inovasi yang telah dilakukan di beberapa buah mahkamah syariah negeri antaranya projek e-Fos (e-Fast Order Sulh) ${ }^{78}$ e-SIAP (e-Shariah Instant Access Procedure) ${ }^{79}$ dan EZNafkah. ${ }^{80}$

Projek inovasi yang dilakukan pada peringkat JKSN dan MSN ini bukanlah pembangunan sistem baharu tetapi merupakan pelaksanaan penambahbaikan proses kerja untuk mempercepat pengurusan yang berkaitan. Walau bagaimanapun terdapat juga beberapa aplikasi yang dibangunkan bagi tujuan memudahkan urusan mahkamah seperti MyReCourt ${ }^{81}$ MySolve ${ }^{82}$ dan E-Locator. ${ }^{83}$ Aplikasi ini boleh dikategorikan

\footnotetext{
77 Syahrul Nizam Junaini \& Nadianatra Musa. (2007). op.cit, h. 50.

78 Ramizah Wan Muhammad \& Khairunnasriah Abdul Salam. (2019). op.cit, h. 36.

79 Ibid., h, 37.

80 Ibid.

81 BH Online, "Kerajaan komited perkasa Mahkamah Syariah". Diakses pada 7 Disember 2020.; [https://www.bharian.com.my/berita/nasional/2019/02/530551/kerajaan-komitedperkasa-mahkamah-syariah].

82 Permohonan Pendaftaran Perceraian atau Cerai dengan Persetujuan Bersama (Orang Islam Sahaja). Diakses pada 1 Disember 2020 [http://mysolve.perak.my/]

83 Laman e-Locator Jakess. Di akses pada 7 Disember 2020.; [http://elocator.jakess.gov.my/].
} 
sebagai suatu transformasi elektronik pada peringkat negeri tetapi tidak menyeluruh digunakan di seluruh Malaysia seperti penggunaan e-Syariah. Oleh itu, pembangunan aplikasi baru yang dibangunkan pada peringkat negeri bagi pengurusan mahkamah syariah wajar diselaraskan di seluruh negeri di Malaysia bagi memastikan penggunaannya dilaksanakan secara optimum dan menyeluruh.

Berdasarkan penyelidikan ini, perkembangan teknologi elektronik pada peringkat kehakiman syariah di Malaysia kurang menunjukkan perkembangan berbanding sistem yang digunakan di institusi kehakiman sivil. Transformasi teknologi elektronik dalam sistem kehakiman Sivil di Malaysia yang menunjukkan kepesatan yang agak memberangsangkan. Pengurusan rekod mahkamah melalui teknologi telah memberikan kesan kepada kerajaan dan rakyat secara keseluruhannya. Pengalaman Malaysia dalam hal ini telah dirujuk dan dijadikan model oleh banyak negara di seluruh dunia. ${ }^{84}$

Mahkamah sivil Malaysia telah mengaplikasikan sistem "e-Courts", ${ }^{85}$ Pengurusan mahkamah sivil telah melaksanakan penggunaan sistem mahkamah elektronik secara khusus antaranya Sistem e-Filing (EFS), Case Management System (CMS), Queue Management System (QMS), Court Recording and Transcribing (CRT),${ }^{86}$ Artificial Intelligence (AI),87 Community and Advocate Portal System (CAP) ${ }^{88}$ dan Video Conferencing System (VCS). ${ }^{89}$ Aplikasi sistem ini telah menunjukkan kesan positif bahkan telah banyak peningkatan dalam implementasi e-Court terhadap penyampaian kehakiman yang telah dibuktikan. ${ }^{90}$ Perkara ini telah dipandang positif oleh JKSS dengan kerjasama pihak SAINS membangunkan i-Syariah agar penyampaian perkhidmatan kehakiman syariah seiring dan selari dengan perkembangan teknologi digital di Sarawak.

84 Gan Chee Keong. (2017). op.cit, h. 407.

85 Nurul Aiqa Mohamad Zain et. al. (2018). op.cit, h. 204.

86 Wan Satirah Wan Mohd Saman \& Abrar Haider. (2012). op.cit, h. 1.

87 Claire Lim \& Rachel Gong. (2020). op.cit, h. 3.

88 Kamal Halili Hassan \& Maizatul Farisah Mokhtar. (2011). op.cit, h. 243.

89 Ibid., h. 240.

90 Nurul Aiqa Mohamad Zain et. al. (2018). op.cit, h. 204. 
Pembangunan sistem i-Syariah ini mengambil kira aspek yang telah dilaksanakan di mahkamah sivil untuk diimplementasikan di mahkamah syariah Sarawak seperti sistem e-Filing (EFS), Case Management System (CMS), Queue Management System (QMS), Court Recording and Transcribing (CRT), Artificial Intelligence (AI), Video Conferencing System (VCS) dan lain-lain lagi. Pembangunan sistem i-Syariah ini dilihat lebih mudah kerana pihak SAINS selaku pihak yang membangunkan sistem mempunyai pengalaman terhadap sistem yang diaplikasikan di mahkamah sivil. Sewaktu penyelidikan ini dijalankan pada akhir tahun 2020, pembangunan sistem i-Syariah fasa kedua masih lagi dibangunkan. Oleh itu aplikasi keseluruhan tidak dapat diteliti memandangkan faktor proses pembangunan sistem yang sedang berjalan. Secara keseluruhannya melalui perbincangan berkenaan dengan transformasi teknologi elektronik dalam sistem pengurusan mahkamah syariah di Malaysia melalui aplikasi e-Syariah dan i-Syariah menunjukkan kesan yang positif walaupun terdapat beberapa kekurangan terhadap sistem e-Syariah. Walau bagaimanapun berdasarkan rangka pembangunan i-Syariah menunjukkan bahawa transformasi teknologi dalam sistem pengurusan kehakiman syariah amat diperlukan masa kini untuk mencapai penyampaian perkhidmatan kehakiman syariah yang maksimum dan efisien. Berdasarkan sejarah implementasi e-Syariah di Malaysia yang pernah dibangunkan oleh SAINS pada awal pembangunan sistem tersebut, tidak mustahil i-Syariah juga boleh dikembangkan dan diguna pakai di negeri-negeri lain, bahkan diimplementasikan di seluruh mahkamah syariah di Malaysia berdasarkan teknologi modul yang telah dibangunkan.

\section{KESIMPULAN}

Transformasi aplikasi teknologi elektronik dalam pengurusan mahkamah syariah di Malaysia memberikan impak yang besar kepada kerajaan dan masyarakat secara menyeluruh. Pelaburan besar yang dibuat oleh pihak kerajaan terhadap pembangunan sistem pengurusan mahkamah syariah melalui sistem e-Syariah telah menampakkan hasil dalam kecekapan dalam pengurusan mahkamah syariah. Transformasi yang dibuat oleh pihak JKSS terhadap pembangunan sistem i-Syariah juga mempunyai matlamat yang sama seperti e-Syariah, iaitu untuk memastikan mutu penyampaian perkhidmatan institusi kehakiman syariah lebih efisien dan komprehensif. Kewajaran dari segi keselarasan terhadap transformasi sistem pengurusan 
mahkamah syariah wajar dilihat secara menyeluruh terhadap teknologi elektronik yang diguna pakai di mahkamah sivil untuk diimplementasikan dalam rangka kerja mahkamah syariah. Pengalaman institusi kehakiman sivil dalam pembangunan e-Court perlu diambil perhatian oleh pihak institusi kehakiman syariah di Malaysia agar perkembangan penggunaan teknologi elektronik yang digunakan tidak ketinggalan. Inovasi dan transformasi bagi penambahbaikan proses kerja yang dibuat oleh JKSN dan MSN perlu dilakukan secara berterusan dan sentiasa dikemaskinikan agar penyampaian perkhidmatan kehakiman syariah dapat dilakukan secara menyeluruh demi kepentingan kerajaan dan masyarakat. Penyelidikan ini mendapati bahawa terdapat usaha yang dibuat oleh institusi kehakiman pada peringkat negeri Sarawak melalui pembangunan sistem i-Syariah merupakan satu tindakan yang tepat berdasarkan masa dan situasi perkembangan teknologi digital di Sarawak. Perkara ini juga perlu dilaksanakan oleh institusi kehakiman pada peringkat Persekutuan untuk memastikan sistem mahkamah syariah sedia ada dikemas kini dan ditambah baik berdasarkan arus globalisasi dan perkembangan teknologi maklumat masa kini.

\section{PENGHARGAAN}

Perbincangan di dalam makalah ini merupakan sebahagian data penyelidikan dibawah tajaan University Malaya COVID-19 Special Research Grant 2020-2021 (UMCSRG) bertajuk "Perbicaraan Kes di Mahkamah Syariah Melalui Sidang Atas Talian: Kajian di Lembah Klang”.

\section{RUJUKAN}

Arahan Amalan JKSM No. 10 Tahun 2001 "Pengumpulan Kes-kes untuk Jurnal Hukum".

Arahan Amalan No. 6 Tahun 2013 "Penggunaan Aplikasi E-Bicara oleh Hakim Syarie".

BH Online. (2020) "Kerajaan komited perkasa Mahkamah Syariah". Diakses pada 7 Disember 2020 daripada https://www.bharian.com.my/berita/ nasional/2019/02/530551/kerajaan-komited-perkasa-mahkamah-syariah

Claire Lim \& Rachel Gong. (2020). Artificial Intelligence in the Courts: AI sentencing in Sabah and Sarawak. Khazanah Research Institute (KRI), 3. 
Diakses daripada http://www.krinstitute.org/assets/contentMS/img/template/ editor/200821\%20AI\%20in\%20the\%20Courts\%20v3_02092020.pdf

Claudius Mitchell Hamarah and Fitri Suraya Mohamad. (2020). "Mathematical Cognition and Big Data Analytics: Are Sarawak Teachers Ready?" Journal of Cognitive Sciences and Human Development, 6(1), March 2020, 1-8.; https:// doi.org/10.33736/jcshd.1591.2020.

Fahmi Zaidi Abdul Razak, Azlina Abu Bakar \& Wan Salihin Wong Abdullah. (2017). How perceived effort expectancy and social influence affects the continuance of intention to use e-government: A study of a Malaysian government service. Electronic Government: An International Journal, 13(1), 69-80.

Gan Chee Keong. (April 2017). Judicial Reforms through the Use of Technology in Malaysia. European Academic Research, V(1), 399-409

Haniff Zainal Abidin. (2006). E-Government implementation in Malaysia: A comparison of Malaysia's and Korea's e-Government (Unpublished Thesis Master in Public Policy). KDI School of Public Policy and Management, Cheongyang Seoul Korea.

Jabatan Kehakiman Syariah Malaysia. (2005). Pekeliling Ketua Pengarah/ Ketua Hakim Syarie Jabatan Kehakiman Syariah Malaysia Bilangan 2 Tahun 2005. "Garis Panduan Bagi Penggunaan Modul dan Kemudahan Peguam dalam Sistem Pengurusan Kes Mahkamah Syariah (SPKMS) e-Syariah" berkuatkuasa pada 19 Oktober 2005.

Jabatan Kehakiman Syariah Sarawak. (2019). DGC Paper No. 2018/02/02 dibentangkan di Wisma Bapa di hadapan Setiausaha Kerajaan negeri Sarawak pada 14 Mac 2019.

Jabatan Kehakiman Syariah Sarawak. Pembentangan Modules Breakdown for RMK-11 (2019-2020) pada 29 April 2020 di Wisma Bapa Malaysia Sarawak Jabatan Kehakiman Syariah Sarawak. Pembentangan Modules Breakdown for RMK-12 pada 27 November 2020 di Sibu Sarawak.

Kamal Halili Hassan \& Maizatul Farisah Mokhtar. (2011). The e-Court system in Malaysia". International Conference on Education and Management Technology, 242.

Khidmat Bantuan Bahagian Sokongan Keluarga. Portal MyGovernment, diakses pada 1 Disember 2020. [https://www.malaysia.gov.my/portal/ content/28866?language $=\mathrm{my}]$.

Koleksi Ucapan Dato' Seri Dr. Mahathir Bin Mohamad. 7 Februari 2003, Hotel Marriot, Putrajaya "Majlis Pelancaran e-Syariah"; diakses pada 1 Disember 2020 melalui laman web https://www.pmo.gov.my/ ucapan $/ ? \mathrm{~m}=\mathrm{p} \& \mathrm{p}=$ mahathir $\& \mathrm{id}=304$ 
Kursus Penggunaan Sistem e-Syariah (Modul e-Bicara) kepada Hakim Syarie JKSS dilaksanakan pada 5 Ogos 2015. Portal Rasmi Jabatan Kehakiman Syariah Sarawak, diakses pada 1 Disember 2020. https://syariah.sarawak.gov. my/modules/web/pages.php?lang=en\&mod=photo_gallery\&sub=photo_ listing\&menu_id=\&sub_id=\&alb=27

Laman E-Locator Jakess. Di akses pada 7 Disember 2020.; http://elocator.jakess. gov.my/

N Norshita, B.Z Halimah, T.S Tengku Mohammad. (2010). Public user assessment of Malaysia's e-government applications. World Academy of Science, Engineering and Technology, 43, 813-817.

Mornizan Yahya, Feridah Nadzar \& Baharom Abdul Rahman. (2012). Examining user acceptance of e-syariah portal among syariah users in Malaysia. Procedia: Social and Behavioral Sciences, 67, 349-359. https://doi.org/10.1016/j. sbspro.2012.11.338.

Muhd Rosydi Muhammad. (2009). Antecedents of IT Alignment in Public Sector: Case of e-Syariah Implementation in Malaysia. UK Academy for Information Systems Conference Proceedings 2009, 1-11. https://aisel.aisnet.org/cgi/ viewcontent.cgi? article $=1044 \&$ context $=$ ukais 2009

Muhd Rosydi Muhammad. (2013). Managing the implementation of e-government in Malaysia: A case of e-syariah. Australian Journal of Basic and Applied Sciences, 7(8), 92-99.

Najaruddin Nedri, Pengurus Projek i-Syariah JKSS. Tem bual pada 1 Disember 2020.

New Sarawak Tribune. State Syariah Dept first to adopt i-Syariah. (6 Julai 2020). Diakses pada 2 disember 2020 https://www.newsarawaktribune.com.my/ state-syariah-dept-first-to-adopt-i-syariah

New Straits Times. Malaysian judiciary makes history, uses AI in sentencing. (19 Februari 2020). Diakses pada 2 disember 2020 https:/www.nst.com.my/ news/nation/2020/02/567024/malaysian-judiciary-makes-history-uses-aisentencing

Noore Alam Siddiquee. (2007). Public service innovations, policy transfer and governance in the Asia-Pacific region: The Malaysian experience. JOAAG, 2(1), 81-91.

Noraini Noordina, Adibah Shuib, Mohammad Said Zainol \& Mohamed Azam Mohamed Adil. (2012). Review on issues and challenges in Islamic inheritance distribution in Malaysia. International Journal of Sustainable Development, 03(12), 27-38.

Norazah Mohd Suki \& T. Ramayah. (2010). User acceptance of the e-government services in Malaysia: Structural equation modelling approach. Interdisciplinary Journal of Information, Knowledge, and Management, 5, 395-413. 
Norlida Ramly, Mohd, Fuaad Said, Choo Wei Chong \& Suhaimi Ab. Rahman. (2015). Analyzing factors that affect e-syariah adoption by shar'ie lawyers. Jurnal Pengurusan, 43, 89-96.

Norman Zakiyy \& Kamal Halili Hassan. (2015). Prospects of using early neutral evaluation in case management of complex civil cases in Malaysia. European Journal of Economics and Business Studies, 1(3), 9-19.

Normi Abdul Malek. (2016). The family institution and its governing laws in Malaysia as a vanguard in protecting the society from social ailments: A shari'ah perspective. IIUM Law Journal, 24(2), 397-413. https://doi. org/10.31436/iiumlj.v24i2.235

Norshidah Mohamed, Husnayati Hussin \& Ramlah Hussein. (2009). Measuring users' satisfaction with Malaysia's electronic government systems. Electronic Journal of e-Government, 7(3), 283 -294.

Norshita Mat Nayan, Halimah Badioze Zaman \& Tengku Mohd Tengku Sembok. (2011). Measurement model to evaluate success of e-government applications through visual relationship. Visual Informatics: Sustaining Research and Innovations, Second International Visual Informatics Conference, IVIC, 295304.

Nurul Aiqa Mohamad Zain, Wan Satirah Wan Mohamad Saman, Saiful Farik Mat Yatin, Abdul Rahman Ahmad, Norshila Saifuddin, Wan Nor Haliza Wan Mokhtar \& Nik Nurul Emyliana Nik Ramlee. (2018). Developing legal framework for e-court in judicial delivery. International Journal of Engineering \& Technology, 7(3.7), 202-205. https://doi.org/10.14419/ijet. v7i3.7.16351

Opening Address and Official Launching of IDECS 2020. Data and Innovation in Accelerating Social and Economic Prosperity, By YAB Datuk Patinggi (Dr) Abang Haji Abdul Rahman Zohari bin Tun Datuk Abang Haji Openg (Chief Minister of Sarawak) 7 October 2020 at Borneo Convention Centre Kuching (BCCK).; official website office of the chief minister of sarawak,; [https://cm.sarawak.gov.my/modules/web/pages. php?mod $=$ speeches\&sub $=$ speeches_view\&menu_id $=\&$ sub_id $=\&$ nid $=79]$

Pekeliling Ketua Pengarah Tanah dan Galian Persekutuan Bilangan 7/2017 "Peritah, Sijil Atau Perakuan Faraid Tidak Boleh Digunakan Bagi Tujuan Pendaftaran Turun Milik Harta Pusaka Si Mati", h. 1.; Official Portal Department of Director General of Lands \& Mines, Ministry of Energy and Natural Resources, https://www.jkptg.gov.my/en/panduan/senaraipekeliling/pekeliling-terbuka/item/pekeliling-ketua-pengarah-tanah-dangalian-persekutuan-bilangan-7-2017

Perlembagaan Persekutuan Malaysia.

Permohonan Pendaftaran Perceraian atau Cerai dengan Persetujuan Bersama (Orang Islam Sahaja). Diakses pada 1 Disember 2020 daripada http:// mysolve.perak.my/ 
Portal Jabatan Kehakiman Syariah Malaysia. "E-Bicara", laman sesawang laman sesawang Jabatan Kehakiman Syariah Malaysia, Diakses pada 20 Februari 2019 daripada http://www.jksm.gov.my/index.php/awam/e-syariah/275-ebicara

Portal Rasmi Pejabat Ketua Pendaftar Mahkamah Persekutuan Malaysia. "Alasan Penghakiman". Diakses pada 2 Disember 2020. http://www.kehakiman.gov. $\mathrm{my} / \mathrm{ms} /$ alasan-penghakiman

Portal the High Court of Sabah and Sarawak. Launching Of The High Court Of Sabah And Sarawak Website In Kuching, Sarawak. Diakses pada 2 Disember 2020 daripada https://judiciary.kehakiman.gov.my/portals/web/home/ article_view/0/460//1

Prashobh Karunakaran. (2014). Electric Power grid optimization for thestate of Sarawak as an example for developing countries. International journal of Electrical and Electronic Engineering \& Telecommunication, 3(2), 97-117.

Ramizah Wan Muhammad \& Khairunnasriah Abdul Salam. (2019). Kejayaan modal insan dan inovasi dalam pentadbiran mahkamah syariah: Membina model antarabangsa. Jurnal Syariah, 27(1), 27-44.

Razlini Mohd Ramli. (2017). e-Government implementation challenges in Malaysia and South Korea: A comparative study. The Electronic Journal of Information Systems in Developing Countries, 80(7), 1-26. https://doi. org/10.1002/j.1681-4835.2017.tb00591.x

Reiling, A.D. (Dory). (2020). Courts and artificial intelligence. International Journal for Court Administration, 11(2), 1-10. DOI: http://doi.org/10.36745/ ijca.343

Rohana Husin Rohaizah Saad \& Zakirah Othman. (2017). E-Kerajaan: Tinjauan dan perlaksanaannya di Malaysia. Journal of Technology and Operations Management, 12(2), (December), 7-14

Roslina Che Soh@Yusoff, Nurhidayah Muhammad Hashim \& Mohd. Na'im Mokhtar. (2017). Bahagian sokongan keluarga membantu anak selepas perceraian: Keberkesanan, cabaran dan perbandingan dengan amalan negara maju. KANUN, 29(2), 60-89.

Syahrul Nizam Junaini \& Nadianatra Musa. (2007). Success Of e-Government Initiative In Sarawak. Public Sector Ict Management Review, 1(1), March, 46-50.

The Star Online. Digital justice: Liew says AI to aid in sentencing for drug, rape trials in Sabah from Feb 17. Diakses pada 2 Disember 2020 daripada https:// www.thestar.com.my/news/nation/2020/01/30/digital-justice-liew-says-aito-mete-out-sentences-for-drug-rape-trials-in-sabah-from-feb-17

Unit Teknologi Maklumat dan Komunikasi JAKESS. (2012). Pelan Strategik ICT Jabatan Kehakiman Syariah Negeri Selangor (JAKESS) 2011-2015. UTMK JAKESS: Selangor, h. 11. 
Utusan Borneo Online. Pengenalan sistem i-Syariah mantapkan Jabatan Kehakiman Syariah Sarawak. Diakses pada 6 Julai 2020 daripada https:// www.utusanborneo.com.my/2020/07/06/pengenalan-sistem-i-syariahmantapkan-jabatan-kehakiman-syariah-sarawak

Wan Satirah Wan Mohd Saman \& Abrar Haider. (2012). "Electronic Court Records Management: A Case Study". Journal of e-Government Studies and Best Practices, Vol. 2012, 1-11. DOI: 10.5171/2012.925115. 